\title{
Efek Tabir Surya Ekstrak Daun Binahong (Anredera cordifolia)
}

\section{Sunscreen Effect of Binahong Leaves Extract (Anredera cordifolia)}

\author{
Nurshalati Tahar*1, Nurfajri Indriani ${ }^{2}$, Faridha Yenny Nonci ${ }^{1}$ \\ ${ }^{1}$ Jurusan Farmasi Fakultas Kedokteran dan Ilmu Kesehatan UIN Alauddin \\ Jl. HM Yasin Limpo No. 36 Sungguminasa Kabupaten Gowa \\ ${ }^{2}$ Mahasiswa Prodi Farmasi Fakultas Kedokteran dan Ilmu Kesehatan UIN Alauddin \\ J1. HM Yasin Limpo No. 36 Sungguminasa Kabupaten Gowa \\ Kontak* : nurshalati.tahar@uin-alauddin.ac.id
}

\begin{abstract}
ABSTRAK
Telah dilakukan penelitian tentang penentuan efek tabir surya ekstrak daun binahong [Anredera cordifolia (Ten.) Steenis]. Pengujian efek tabir surya dilakukan dengan menghitung nilai transmisi eritema (\%Te), transmisi pigmentasi (\%Tp), dan nilai SPF. Daun binahong diekstraksi dengan metode maserasi menggunakan pelarut etanol 96\%. Pengujian efek berdasarkan serapan dan transmisi pada panjang gelombang UV yang diukur dengan spektrofotometer. Hasil pengujian nilai rata - rata persen transmisi eritema (\% Te) pada konsentrasi $(300 \mathrm{ppm}, 350$ ppm, 400 ppm, dan 450 ppm) berturut - turut adalah 31,52\%;23,90\%; 20,27\%; 14,71\%. Sedangkan perhitungan nilai rata- rata persen transmisi pigmentasi (\% Tp) yang diperoleh berturut-turut adalah 20,95\%; 15,9\%; 11,98\%; $8,26 \%$. Nilai rata-rata SPF berturut-turut adalah 4,$36 ; 5,82 ; 7,44 ; 10,45$. Hasil yang didapatkan menunjukkan bahwa Ekstrak Daun Binahong berefek sebagai tabir surya pada konsentrasi 450 ppm. Efek termasuk kategori fast tanning untuk proteksi eritema dan proteksi totalblock untuk proteksi pigmentasi.
\end{abstract}

Kata kunci: Daun binahong, Tabir surya, SPF, \%Te, \% Tp

\begin{abstract}
Research on the determination of the sunscreen effect of binahong leaves extract [Anredera cordifolia (Ten.) Steenis] had been conducted. Sunscreen effect calculated by the value of erythema transmission (\% Te), pigmentation transmission (\% Tp), and SPF value. Binahong leaves were extracted by maceration method using 96\% ethanol. Testing the effect is based on absorption at the UV wavelength measured by a spectrophotometer. The test results of the average percent transmission rate of erythema (\% Te) at concentrations $300 \mathrm{ppm}, 350 \mathrm{ppm}, 400$ ppm, and $450 \mathrm{ppm}$ were $31.52 \% ; 23.90 \% ; 20.27 \% ; 14.71 \%$. While the calculation of the average value of percent transmission of pigmentation (\% Tp) obtained respectively is $20.95 \% ; 15.9 \% ; 11.98 \% ; 8.26 \%$. The average SPF values were $4.36 ; 5,82 ; 7.44 ; 10,45$. The results showed that the Binahong Leaves Extract effects as a sunscreen at a concentration of $450 \mathrm{ppm}$. Effect is fast tanning category for erythema protection and totalblock protection for pigmentation protection.
\end{abstract}

Key word: Binahong leaves, Sunscreen, SPF, \%Te, \% Tp.

\section{PENDAHULUAN}

Indonesia adalah salah satu negara dengan paparan sinar matahari yang tinggi dan sebagian besar penduduknya bekerja diluar ruangan sehingga memerlukan suatu perlindungan kulit. Sinar matahari selain memberi manfaat juga mempunyai dampak buruk pada kulit jika terpapar secara berlebihan. Sinar ultraviolet yang disebut UVB dan UVA, kedua sinar ultraviolet ini bekerja secara sinergis sehingga dibutuhkan suatu pencegahan atau perlindungan untuk mengurangi dampak buruk pada kulit akibat radiasi tersebut (Erlina, Adelsa, \& Putri, 2015). 
Paparan sinar UV pada dasarnya me miliki manfaat dalam pembentukan vitamin D yang digunakan untuk metabolisme pembentukan tulang dan sistem imun. Selain itu, radiasi sinar UV juga dapat digunakan untuk terapi psoriasis dan vitiligo. Akan tetapi, paparan sinar matahari secara berlebih merupakan mediator eksogen utama terjadinya kerusakan pada kulit yang dapat mempercepat terjadinya penuaan dan resiko terjadinya kanker pada kulit (Isriany, 2014). Jika penyinaran matahari terjadi secara berlebihan, jaringan epidermis kulit tidak cukup mampu melawan efek negatif tersebut sehingga diperlukan perlindungan baik secara fisik dengan menutupi tubuh dan secara kimia dengan menggunakan tabir surya (Karina, 2015).

Penggunaan tabir surya merupakan salah satu upaya yang dapat dilakukan untuk melindungi kulit dari efek merugikan yang disebabkan oleh radiasi UV. Kemampuan suatu tabir surya dapat melindungi kulit dengan menunda eritema dinyatakan dengan Sun Protection Factor (SPF) (Hassan, Dorjay, Sami, \& Anwar, 2013). Tabir surya dapat bersumber dari bahan alam dan hasil sintesis kimia.

Tabir surya chemical umumnya bersifat alergenik, yang dapat menyebabkan fotoiritasi, fotosensitasi dan dermatitis kontak (Cefali, Ataide, Moriel, Foglio, \& Mazzola, 2016; Saewan \& Jimtaisong, 2013). Meskipun ada berbagai produk kosmetik hypoallergenic untuk kulit sensitif, produk tabir surya masih jarang ditemukan (More,
Sakharwade, Tembhurne, \& Sakarkar, 2013). Bahan aktif tabir surya yang bersumber dari bahan alam dapat menutupi kebutuhan konsumen kulit sensitif terhadap kosmetika tabir surya (Warnida \& Nurhasnawati, 2017).

Di dalam tumbuhan terdapat zat alami yang dapat diekstrak dan dapat bertindak sebagai sumber potensial tabir surya karena bersifat fotoprotektif. Hal tersebut memberikan sedikit gambaran mengenai kemampuan tanaman untuk melindungi kulit melalui senyawa yang terkandung didalam tanaman yang berupa senyawa bioaktif seperti senyawa fenolik dan didukung oleh adanya senyawa yang bersifat antioksidan (Prasiddha, Laeliocattleya, Estiasih, \& Maligan, 2016).

Pencarian senyawa-senyawa dari bahan alam menjadi perhatian utama sekarang ini, beberapa senyawa antioksidan dapat dihasilkan dari produk alami. Salah satu tanaman yang menghasilkan senyawa antioksidan adalah daun binahong. Tanaman ini belum banyak diketahui manfaatnya oleh masyarakat Indonesia, sehingga menarik untuk diteliti (Manoi, 2009).

Penelitian sebelumnya yang dilakukan oleh Parwati, Napitupulu, \& Diah (2014) menunjukkan bahwa ekstrak etanol daun binahong mempunyai aktivitas antioksidan yang tinggi dengan nilai $\mathrm{IC}_{50}$ sebesar 40,27 ppm, lebih baik daripada $\mathrm{IC}_{50}$ yang dihasilkan vitamin $\mathrm{C}$ yaitu sebesar 49,2 ppm. Hal ini menjelaskan bahwa kemampuan menangkap radikal bebas ekstrak daun binahong termasuk dalam golongan sangat kuat dikarenakan nilai $\mathrm{IC}_{50}$ yang diperoleh dari perhitungan kurang dari 50 ppm, yaitu 40,27 
ppm. Hal ini sesuai dengan pernyataan Molyneux dalam jurnal Parwati, Napitupulu, \& Diah (2014) bahwa tingkat kekuatan antioksidan menggunakan DPPH dapat digolongkan menurut $\mathrm{IC}_{50}$. Semakin kecil nilai $\mathrm{IC}_{50}$ berarti semakin kuat daya antioksidannya.

Berdasarkan uraian tersebut daun binahong berpotensi sebagai tabir surya. Namun belum ada penelitian lebih lanjut yang menguji potensi tersebut. Oleh karena itu, perlu dilakukan penelitian untuk mengetahui potensi daun binahong sebagai tabir surya dan menghitung nilai SPF.

\section{METODOLOGI PENELITIAN}

\section{Ekstraksi sampel}

Sampel daun binahong [Anredera cordifolia (Ten.) Steenis] yang telah diserbukkan menjadi simplisia kemudian diekstraksi menggunakan pelarut etanol $96 \%$. Metode ekstraksi yang digunakan dalam penelitian ini adalah maserasi. Simplisia ditimbang sebanyak 130 gr kemudian dimasukkan dalam wadah maserasi. Kemudian dituangi pelarut etanol $96 \%$ sebanyak 3 liter, ditutup dan dibiarkan selama 3 hari terlindung dari cahaya, sambil sesekali diaduk. Setelah 3 hari kemudian disaring dan diambil sarinya. Ampas ditambah kembali dengan cairan penyari dan diulangi hingga tiga kali. Sari kemudian dipekatkan dan diuapkan dengan rotary evaporator dengan suhu $60^{\circ} \mathrm{C}$ sampai diperoleh ekstrak kental. Ekstrak kental ini kemudian larutkan untuk diukur serapan dan transmitan menggunakan spektrofotometer uv vis.

\section{Pengukuran Transmisi dan Serapan dengan Spektrofotometer}

Data yang dikumpulkan adalah transmisi dan serapan pada panjang gelombang 290$400 \mathrm{~nm}$ untuk diolah menjadi adalah nilai transmisi eritema (\% Te), transmisi pigmentasi (\% Tp), dan nilai SPF.

Ekstrak daun binahong dilarutkan dalam etanol pa hingga diperoleh larutan dengan konsentrasi 1000 ppm (larutan stok). Larutan dengan konsentrasi 300 ppm, 350 ppm, 400 ppm, dan 450 ppm dengan mengencerkan larutan stok. Setiap larutan diukur persen transmisinya dengan menggunakan spektrofotometer pada panjang gelombang 292,5-372,5 nm dan serapan pada panjang gelombang 290-400 $\mathrm{nm}$ dengan interval 5,0 $\mathrm{nm}$ yang diukur dengan alat spektrofotometer.

\section{Nilai Sun Protecting Factor (SPF)}

SPF dihitung berdasarkan luas area dibawah kurva serapan (AUC) dari nilai serapan pada panjang gelombang 290-400 nm dengan interval $5 \mathrm{~nm}$. Nilai SPF masingmasing konsentrasi ditentukan menggunakan rumus berikut

$$
\log S P F=\frac{A U C}{\lambda_{n}-\lambda_{1}}
$$

dimana $\lambda_{\mathrm{n}}=$ panjang gelombang terbesar (dengan $\mathrm{A}>0,05$ untuk ekstrak dengan $\mathrm{A}>0,01$ untuk sediaan dan $\lambda_{1}=$ panjang gelombang terkecil $(290 \mathrm{~nm})$.

\section{Nilai Persentase Transmisi Eritema}

Nilai transmitan pada berbagai panjang gelombang digunakan untuk menghitung 
persen transmisi eritema ( $\% \mathrm{Te}$ ), dihitung dengan rumus

$$
\% T e=\frac{E e}{\Sigma F e}=\frac{\Sigma(T x F e)}{\Sigma F e}
$$

dimana $\mathrm{T}=$ nilai transmisi pada berbagai panjang gelombang $292,5-317,5 \mathrm{~nm}, \mathrm{Fe}=$ Fluks eritema, $\mathrm{Ee}=\Sigma \mathrm{T} . \mathrm{Fe}=$ banyaknya fluks eritema.

\section{Nilai Persentase Transmisi Pigmentasi}

Nilai persen transmisi pigmentasi $(\% T p)$ dihitung dengan rumus

$$
\% T p=\frac{E p}{\Sigma F p}=\frac{\Sigma(T x F p)}{\Sigma F p}
$$

dimana $\mathrm{T}=$ nilai transmisi pada berbagai panjang gelombang, $\mathrm{Fp}=$ Fluks pigmentasi, $\mathrm{Ep}=\Sigma \mathrm{T} . \mathrm{Fp}=$ banyaknya fluks pigmentasi.

\section{HASIL DAN PEMBAHASAN}

Sinar ultraviolet dapat dibedakan menjadi 3, yaitu sinar UV-A dengan panjang gelombang 320-400 nm, UV-B dengan panjang gelombang 290-320 nm, dan UV-C dengan panjang gelombang 200-290 nm, ketiga sinar tersebut mempunyai panjang gelombang berbeda dan efek radiasi yang berbeda pula. Sinar UV-A mempunyai efek radiasi, berupa pigmentasi yang menyebabkan kulit berwarna coklat dan kemerahan. Sinar UV-B memiliki efek radiasi, yang menyebabkan eritema (kemerahan) hingga dapat menyebabkan kanker kulit bila terlalu lama terkena radiasi ini. Sedangkan sinar UV $\mathrm{C}$ tertahan pada lapisan atmosfer paling atas dari bumi dan tidak sempat masuk ke bumi karena adanya lapisan ozon (Tranggono \&
Latifah, 2007). Sehingga dalam penelitian ini, efek tabir surya diukur dari panjang gelombang 290-400 (UVA dan UV B).

Secara alamiah, manusia memiliki perlindungan alami terhadap sinar UV yaitu dengan cara mengeluarkan keringat, penebalan stratum korneum dan pembentukan melanin pada epidermis. Akan tetapi jika terjadi kontak secara berlebihan dengan paparan sinar UV yang terlalu lama dapat menjadikan sistem alamiah tersebut tidak berfungsi dengan baik sehingga menyebabkan efek yang merugikan bagi kulit. Oleh karena itu, diperlukan senyawa tabir surya untuk melindungi kulit dari radiasi UV secara langsung (Cumpelik, 1972). Salah satu bahan yang dapat digunakan melindungi kulit manusia bersumber dari bahan alam, yaitu daun binahong.

Penelitian ini menggunakan Daun Binahong. Pemilihan daun binahong pada penelitian kali ini berdasarkan penelitian sebelumnya bahwa daun ini memiliki aktivitas antioksidan yang kuat serta memiliki kandungan senyawa flavonoid yang diduga dapat berpotensi sebagai tabir surya.

Metode ekstraksi yang digunakan pada penelitan ini adalah metode maserasi. Metode ini dipilih karena menghindari pemanasan yang dapat merusak flavonoid dan antioksidan. Selain itu metode maserasi dipilih karena memiliki beberapa kelebihan diantaranya selain murah dan mudah dilakukan, juga akan terjadi proses pemecahan dinding dan membran sel yang 
Tabel. 1 Nilai Rata-rata SPF daun Binahong

\begin{tabular}{ccccc}
\hline \multirow{2}{*}{ Replikasi } & \multicolumn{4}{c}{ Nilai SPF ekstrak } \\
\cline { 2 - 5 } & $300 \mathrm{ppm}$ & $350 \mathrm{ppm}$ & $300 \mathrm{ppm}$ & $450 \mathrm{ppm}$ \\
\hline I & 4.34 & 5.92 & 7.01 & 9.97 \\
II & 4.36 & 5.99 & 7.55 & 11.04 \\
III & 4.40 & 5.56 & 7.78 & 10.35 \\
\hline Rata-rata & 4.36 & 5.82 & 7.44 & 10.45 \\
\hline
\end{tabular}

Tabel. 2 Nilai Persen Transmisi Eritema daun Binahong

\begin{tabular}{ccccc}
\hline \multirow{2}{*}{ Replikasi } & \multicolumn{4}{c}{ Persen Transmisi Eritema (\%) } \\
\cline { 2 - 5 } & $300 \mathrm{ppm}$ & $350 \mathrm{ppm}$ & $300 \mathrm{ppm}$ & $450 \mathrm{ppm}$ \\
\hline I & 31,74 & 24,82 & 22,30 & 15,74 \\
II & 31,27 & 23,49 & 19,68 & 14,06 \\
III & 31,56 & 23,41 & 18,83 & 14,34 \\
\hline Rata-rata & 31,52 & 23,90 & 20,27 & 14,71 \\
\hline
\end{tabular}

Tabel. 3 Nilai Persen Transmisi Pigmentasi daun Binahong

\begin{tabular}{ccccc}
\hline \multirow{2}{*}{ Replikasi } & \multicolumn{4}{c}{ Persen Transmisi Pigmentasi (\%) } \\
\cline { 2 - 5 } & $300 \mathrm{ppm}$ & $350 \mathrm{ppm}$ & $400 \mathrm{ppm}$ & $450 \mathrm{ppm}$ \\
\hline I & 21,35 & 16,55 & 12,45 & 8,67 \\
II & 20,67 & 15,59 & 11,92 & 8,10 \\
III & 20,82 & 15,58 & 11,59 & 8,02 \\
\hline Rata-rata & 20,95 & 15,90 & 11,98 & 8,26 \\
\hline
\end{tabular}

terjadi di dalam dan luar sel akibat adanya tekanan, sehingga metabolit sekunder yang ada dalam sitoplasma terdesak keluar dan akan terlarut dalam pelarut [Lenny, 2006 dalam (Fanna Veronita \& Mursiti, 2017)]. Pelarut etanol digunakan karena merupakan salah satu pelarut yang mempunyai extractive power yang terbaik untuk hampir semua jenis senyawa yang mempunyai berat molekul rendah seperti flavonoid. Senyawa ini yang bersifat polar sehingga akan terikat dengan etanol [Afrianti, 2014 (Fanna Veronita \& Mursiti, 2017)]. Hasil ekstraksi dengan berat simplisia $130 \mathrm{~g}$ diperoleh ekstrak sebesar $14 \mathrm{~g}$ dengan persen rendamen $10.77 \%$.

Penentuan potensi tabir surya dari ekstrak daun binahong dilakukan secara in vitro dengan metode spektrofotometer pada rentang panjang gelombang ultraviolet. Ekstrak dilarutkan dalam pelarut etanol pa dan diukur serapan dan transmitannya. Penentuan efektivitas tabir surya didasarkan pada nilai persen transmisi eritema (\%Te) dan transmisi pigmentasi (\% Tp) serta dengan menghitung nilai SPF. Suatu sediaan tabir surya dapat dikatakan memiliki efektivitas yang baik apabila sediaan tersebut memiliki nilai SPF yang tinggi, serta memiliki persen transmisi eritema dan persen transmisi pigmentasi yang rendah.

Hasil pengukuran nilai SPF menunjukkan bahwa ekstrak dengan konsentrasi 300 ppm dan 350 ppm termasuk ketegori proteksi sedang karena berada pada range 4-6, pada konsentrasi ekstrak 400 ppm menunjukkan bahwa ektrak termasuk kategori proteksi 
ekstra kerena berada pada range 6-8, sedangkan pada konsentrasi ekstrak 450 ppm menunjukkan bahwa ekstrak termasuk kategori proteksi maksimal karena berada pada range 8-15. Konsentrasi ekstrak yang terbaik adalah 450 ppm karena memiliki daya proteksi maksimal dengan nilai SPF 10,45 yang artinya dapat melindungi kulit lebih lama dibawah sinar matahari.

Nilai transmisi eritema ekstrak 450 ppm termasuk kategori fast tanning untuk eritema berdasarkan pada nilai persentase Te sebesar $14,71 \%$ karena berada pada range $10-18 \%$. Ekstrak pada konsentrasi tersebut dapat melindungi atau mencegah kulit dari terjadinya kemerahan atau eritema. Sedangkan untuk ketiga konsentrasi 300 ppm, 350 ppm dan 400 ppm belum mencapai nilai minimum untuk penggolongan proteksi eritema. Konsentrasi tersebut belum bisa melindungi atau mencegah kulit dari eritema/kemerahan pada kulit, namun jika dilihat dari nilai SPF yang didapatkan yaitu termasuk proteksi sedang hingga proteksi ekstra, artinya ekstrak pada konsentrasi tersebut masih dapat memperpanjang kontak kulit dibawah sinar matahari sehingga masih dapat memperpanjang waktu sebelum terjadinya eritema pada kulit.

Persentase pigmentasi ekstrak 300 ppm, 350 ppm, 400 ppm, dan 450 ppm termasuk kategori total block untuk penggolongan proteksi pigmentasi. Persentase pigmentasi ini berada pada range 3-40\%, yang artinya ekstrak dapat melindungi atau mencegah terjadinya pigmentasi pada kulit. Ekstrak daun binahong memiliki penyerapan UV-A yang cukup baik jika dilihat dari persen ratarata pigmentasi yang menunjukkan proteksi totalblock. Spektrum sinar UV-A ini dapat menyebabkan warna gelap pada kulit (pigmentasi) dengan panjang gelombang 320$400 \mathrm{~nm}$ (Soeratri, Ifansyah, \& Fitrianingrum, 2005).

Faktor yang dapat mempengaruhi penentuan nilai SPF yaitu adanya perbedaan konsentrasi dari tabir surya. Perbedaan konsentrasi ini dapat menambah atau mengurangi penyerapan sinar UV dari setiap tabir surya (More, Sakharwade, Tembhurne, \& Sakarkar, 2013). Hal diatas menunjukkan bahwa seiring bertambahnya konsentrasi, maka daya proteksi tabir surya juga bertambah. Nilai SPF ekstrak Daun Binahong menunjukkan seiring bertambahnya konsentrasi maka nilai SPF ekstrak juga semakin besar.

\section{KESIMPULAN}

Nilai SPF Ekstrak Daun Binahong dengan proteksi sedang pada 300 ppm dan 350 ppm yaitu sebesar 4,36 dan 5,82, proteksi ekstra pada 400 ppm yaitu 7,44, dan proteksi maksimal pada 450 ppm, yaitu 10,45. Ekstrak daun Binahong berefek sebagai tabir surya pada kosentrasi 450 ppm termasuk eritema fast tanning dan pigmentasi totalblock, serta SPF dengan proteksi maksimal. 


\section{DAFTAR PUSTAKA}

Cefali, L. C., Ataide, J. A., Moriel, P., Foglio, M. A., \& Mazzola, P. G. (2016). Plantbased active photoprotectants for sunscreens. International Journal of Cosmetic Science, 38(4), 346-353. doi:10.1111/ics.12316

Cumpelik, B. M. (1972). Analytical Procedures and Evaluation of Sunscreens. Journal of the Society of Cosmetic Chemists, 23(6), 333-345.

Erlina, Y., Adelsa, A., \& Putri, A. (2015). Penentuan nilai SPF (Sun Protection Factor) Ekstrak Etanol $70 \quad \% \quad$ Temu Mangga (Curcuma mangga) dan Krim Ekstrak Etanol $70 \%$ Temu Mangga (Curcuma mangga) secara In Vitro Menggunakan Metode Spektrofotometri. Majalah Kesehatan Fakultas Kedokteran Universitas Brawijaya, 2(1).

Fanna Veronita, N. W., \& Mursiti, S. (2017). Isolasi dan Uji Aktivitas Antibakteri Daun Binahong serta Aplikasinya sebagai Hand Sanitizer. Indonesian Journal of Chemical Science, 6(2).

Hassan, I., Dorjay, K., Sami, A., \& Anwar, P. (2013). Sunscreens and Antioxidants as Photo-protective Measures: An update. Our Dermatology Online, 4(3), 369-374. doi:10.7241/ourd.20133.92

Isriany. (2014). Desain Sediaan Tabir Surya. Makassar. Alauddin University Press.

Karina, N. (2015). Penentuan Nilai Sun Protection Factor (SPF) Ekstrak dan Fraksi Rimpang Lengkuas (Alpinia galanga) sebagai Tabir Surya dengan Metode Spektrofotometer UV-Vis. Pontianak: Prodi Farmasi Fakultas Kedokteran Universitas Tanjungpura .

Manoi, F. (2009). Binahong (Anredera cordifolia (Ten) Steenis) sebagai obat.
Jurnal Warta Penelitian dan

Pengembangan Tanaman Industri.

More, B., Sakharwade, S., Tembhurne, S., \& Sakarkar, D. (2013). Evaluation of Sunscreen Activity of Cream Containing Leaves Extract of Butea monosperma for Topical Application. International Journal of Research in Cosmetic Science.

Parwati, N. K., Napitupulu, M., \& Diah, A. W. (2014). Uji Aktivitas Antioksidan Ekstrak Daun Binahong (Anredera Cordifolia (Tenore) Steenis) dengan 1,1Difenil-2-Pikrilhidrazil

(DPPH) Menggunakan Spektrofotometer UV-Vis. Jurnal Akademika Kimia, 3(4), 206-213.

Prasiddha, I. J., Laeliocattleya, R. A., Estiasih, T., \& Maligan, J. M. (2016). Potensi senyawa bioaktif rambut jagung (zea mays 1.) untuk tabir surya alami: kajian pustaka. Jurnal Pangan Dan Agroindustri. Jurnal Pangan dan Agroindustri, 4(1).

Saewan, N., \& Jimtaisong, A. (2013). Photoprotection of Natural Flavonoid. Journal of Applied Pharmaceutical Science, $\quad 3(9), \quad$ 129-141. doi:7324/japs.2013.3923

Soeratri, W., Ifansyah, N., \& Fitrianingrum, D. (2005). Penentuan Stabilitas Sediaan Krim Tabir Surya Dari Bahan Ekstrak Rimpang Kencur (Kaempferia galanga L.). Berk. Penel. Hayati, 10, 103-105. doi:10.23869/bphjbr.10.2.20055

Tranggono, R. I., \& Latifah, F. (2007). Buku Pegangan Ilmu Pengetahuan Kosmetik. Jakarta: PT Gramedia Pustaka Utama.

Warnida, H., \& Nurhasnawati, H. (2017). Efektivitas Ekstrak Daun Kokang (Lepisantes amoena) Sebagai Tabir Surya; Eksplorasi Kearifan Lokal Kalimantan Timur. Jurnal Penelitian Ekosistem Dipterokarpa, 3(2). 